AIOHI II. 4 International Issue

\title{
Jakub Jirsa
}

\section{Value pluralism, Sophocles' Antigone and libe-ralism}

"Although the city must rest on both the arts and the gods (their laws), its two supports are not in harmony with one another."

Seth Benardete's commentary on the Antigone

The relationship between ancient culture, philosophy and literature on the one hand, and modern political thought on the other is a rather complicated one. Two opposite methodological approaches towards this ancient heritage could be observed. Firstly, there is the tradition which, I believe, originates in modern political philosophy with Machiavelli and Hobbes. This tradition uses ancient Greek and Roman sources in order to develop one's own and essentially modern political concepts and philosophies. ${ }^{i}$

i Machiavelli is more positive in the use of ancient sources, cf. The Prince and, of course, Discourses on Livy; Hobbes on the other hand reacts critically on Aristotle's conception of natural sociality of men (cf. De Cive), however his writings cannot deny that the author is one of first modern translators of Homer and Thucydides. 
From the twentieth century one can name suchdifferent scholars as Hannah Arendt, Leo Strauss or J. Peter Euben who use ancient thinkers as archai of their own political philosophy.

Secondly, Benjamin Constant warned his fellow gentlemen of Athénée Royal in Paris not to accept the ancient concepts into modern political theories: they not only differ, but such a blind takeover might actually produce unwanted results. ${ }^{i}$ Perhaps the most compact condemnation of the importance of ancient philosophy for contemporary political theory is Holmes' article "Aristippus in and out of Athens". ii Ancient society and its structure differs, according to Holmes, so vastly from our modern (or even postmodern) one, that the political theories and concepts of the ancients are simply anachronistic as much as, for example, their carriages when compared to automobiles.

Moreover, my thesis needs further qualification, since I am trying to trace some liberal ideas and values in ancient tragedy, namely in Sophocles' Antigone. ${ }^{\text {iii }}$ Looking for

i Cf. Constant's famous speech The Liberty of Ancients Compared with that of the Moderns (1819).

ii Holmes (1979a); cf. discussion by Nichols (1979) and Holmes (1979b).

iii For the discussion of political relevance on ancient tragedy cf. Griffin (1998), Seaford (2000) and Rhodes (2003). 
liberal values in ancient texts cannot be more than a liberal fiction, since there is nothing like liberalism in ancient Greece. Modern liberalism might find its origins in Locke or Constant, who most probably coined the term as a political label some years after the French revolution. ${ }^{\mathrm{i}}$ And I tend to agree with Holmes that " $\ldots$ the fundamental principles of modern liberalism cannot be made fully intelligible without explicit reference to the highly differentiated institutional order of modern 'bourgeois' society." ii

However, I do not take the skeptical standpoint that ancient texts are of no use for modern political theory. I agree with Berlin, Williams and Gray that value pluralism forms a part of the moral basis of modern liberalism, ${ }^{\mathrm{iii}}$ and in this case "turning to Greek tragedy can help political theory respond to the problem of moral grounding because

i Cf. Vincent (2000): 609; Vincent claims that Constant first used the adjective liberal in 1797, opposed to him I was able to trace down Constant's first use of the adjective liberal to a letter from 19.4.1794, cf. Melegari (1895): 211.

ii Holmes (1979b): 135.

iii Cf. Crowder (1994), Berlin and Williams (1994), Williams (1999): xviii-xix, Gray (2000), Gray (1993): 283-328. 
it implies a moral epistemology of active citizenship." Therefore, I will not claim that Sophocles was a liberal thinker or that some character of his plays is a quasi-modern liberal. That would be anachronistic nonsense. Rather, and more carefully, my claim is that in the Antigone one discovers certain liberal ideas; I will try to show that these liberal values appear in the middle between Antigone's and Kreon's radical position in a similar manner as Constant's liberalism appears in between of the supporters of ancient regime and Jacobins.

In the first part of this essay I will interpret the concept of value pluralism and what could be called tragic about it. Unsurprisingly, I will rely on works of Isaiah Berlin and Bernard Williams. Then I will try to show where to spot some reflections upon the value conflict in Sophocles' Antigone. I will argue that the conflict presented by the play is explicitly reflected by Ismene and Haimon. In the conclusion I will come back to the relation between value pluralism, liberalism and tragedy.

i

Barker (2009): 9. I endorse this thought despite the fact that Baker is later far too optimistic concerning Greek political theory and democracy. 
AlӨHP II. 4 International Issue

\section{Isaiah Berlin and Bernard Williams on value pluralism}

There can hardly be a more profound topic from the murky field between moral and political philosophy than pluralism. The discussion can take many forms; I will concentrate on the so-called value pluralism as it is sketched in works of Isaiah Berlin. The place, where to look for the most comprehensive presentation of this idea is the eighth section of Berlin's essay "Two Concepts of Liberty". The thought proceeds negatively from the critique of any kind of "final solution" (notice the heavily loaded term) resting on an assumption that "all the positive values in which men have believed must, in the end, be compatible, and perhaps even entail one another." "ii The "rational metaphysicians" as Berlin calls the advocates of the competing view, merely disdain any attempt to abandon the notion of the final harmony. Yet, according to Berlin this final harmony cannot be proved or justified except by a priori guarantee, which is not available.

i I use the text of this essay in Berlin (2004).

ii Berlin (2004): 212.

iii I take it that Skorupski (1996): 108-113 attempts to develop such a guarantee; strong pluralism according to him collapses into contradictions and therefore it is irrational to hold it. 
Berlin's methodological starting point is a certain phenomenology of our everyday empirical experience and common knowledge of our human lives. He stresses the particularity of situations in our lives in which we act, decide and choose. The ordinary experience of the world, Berlin continues, is that there are "choices between ends equally ultimate, and claims equally absolute, the realisation of some of which must inevitably involve the sacrifice of others." If anyone suggests some kind of ideal harmony of all values in our lives (or in the most perfect form of a human life), according to Berlin such a thinker merely presents a "dogmatic certainty". Therefore, when Berlin later summarizes his idea he does not talk only about the possibility of conflict but also about its tragedy. ${ }^{\text {i }}$

I take it that the entire "master idea" of value pluralism has not only two, but three different components: (a) critique of the unwarranted "final solutions"; (b) plurality and conflict of values; and finally (c) the tragic loss entailed in the impossibility of pursuing all the available options. Berlin considers each of these components as vital for his theory. I will try to show that the third step, namely acknowledging the loss involved in acting under the strain of value conflict, naturally completes

i $\quad$ Berlin (2004): 214. 
AIOHI II. 4 International Issue

his idea and that without it the theory would be not only incomplete but incoherent as well.

Berlin offers his critique of "rational metaphysics" in several essays and his argument focuses primarily on the unwanted ethical and political results of these doctrines. ${ }^{\mathrm{ii}}$ The essay "The Decline of Utopian Ideas in the West" provides us with three propositions which Berlin considers essential to western political thought and its utopian tendencies:

to all genuine questions there can only be one correct answer, all the other answers being incorrect;

a method exists for the discovery of these correct answers; and finally

all the correct answers must, at the very least, be compatible with one another. ${ }^{\text {iii }}$

i Since he calls his philosophical opponents "rational metaphysicians" (cf. above), I assume that they are involved in rational metaphysics and I use the expression accordingly.

ii Cf. especially "The Decline of Utopian Ideas in the West", "From Hope and Fear Set Free" or "The Pursuit of the Ideal"; all of these essays combine the approach of the history of ideas with critical insights of a philosopher,althought these arguments have to be extracted from the text.

iii $\quad$ Berlin (1990): 24. 
These are primarily methodological points. They establish the way one should (or in Berlin's eyes should not) think about the human world and its problems. The first and last points are in open opposition to Berlin's conception of value pluralism which allows for several correct answers, for example, on the question how should I live or what should I do. The last point explicitly denies this plurality of equal values; it either supports a scheme with one value only (upon which all other secondary values can be reduced) or a plurality with a hierarchy of values, so that one and only one value is always on top.

This methodology heavily stresses the positive and liberating role of knowledge, expert knowledge and possibly even paternalism in one's life. This knowledge is transmitted in sacred texts (of either religious or scientific nature) and serves as a basis for strictly hierarchical arrangement of a society structured by the levels of knowledge. Berlin's critique targets mainly many unwanted social and political results of such a theory - authoritarian societies, totalitarian states, oppression of freedom and denial of basic liberties.

Despite the fact that "From Hope and Fear Set Free" deals mainly with ancient philosophy and its heritage, Berlin offers another triad which, according to my understanding of it, supplies the ontological grounds for the 
AlӨHP II. $4 \quad$ International Issue

method stated above. The views discussed by Berlin share the following points:

- $\quad$ things and persons possess natures - definite structures independent of whether or not they are known;

- these natures or structures are governed by universal and unalterable laws;

- these structures and laws are, at least in principle, all knowable. ${ }^{\mathrm{i}}$

This knowledge again liberates the knower from all troubles and traps not only in one's thought but in his or her actions as well. This world of fully intelligible structures forms than can be cognized in accordance with the method mentioned above.

However, according to Berlin, this word-view is utterly false.

The world we live in is, according to him, a world of plural values which can come to a conflict. Our human goals are many and not all of them commensurable. As Berlin summarizes in "Two Concepts of Liberty": "the ends of men are many, and not all of them are in principle

i Berlin (2004): 253; echoed in "The Decline of Utopian Ideas in the West", Berlin (1990): 30 . 
compatible with each other, [...] the possibility of conflict can never be eliminated from human life, either personal or social." ${ }^{\text {, }}$ This notion of conflict needs further explanation. In "The Pursuit of Ideal" Berlin suggests three different sets of examples: incompatibility between cultures or different social groups, profound conflict between liberty and equality and finally Sophocles' tragic figure Antigone. The range over which the theory can be applied is thus quite wide (or even all embracive). It covers a cultural conflict, necessary choice between mutually exclusive social and political institution based on different values, choice of one's way of life and, finally, an individual conflict of motivations.

All these areas exhibit the same pattern of conflict between different values. These values are not subjective or relative - were it so, there would be no genuine conflict between values, which Berlin endorses. There could be a conflict between individuals or societies with different (subjective) values or a conflict between two different points of view supporting different (relative) values. ${ }^{\text {ii }}$ But

i $\quad$ Berlin (2004): 214, cf. 216.

ii For example in a society with wide economic inequality the values and interest of the poor are different from those of the rich; if we assume that the values are relative to each of the social groups (i.e. the values of the poor are not values for the rich and vice versa) it makes no sense to talk about a conflict between values. There is a conflict between social groups whose values basically do not ever meet to 
according to Berlin "there is a world of objective values" and these are the ends pursued for their own sake. Although some values are not my values, I can understand (and respect) them and can perhaps imagine what would it be like to live with holding them. Berlin was a realist about the nature of values; values do exist, they are real, objective and plural. ${ }^{\text {ii }}$ Therefore Thomas Nagel calls his metaethical standpoint "realistic pluralism". iii It is important to add a further classification: Berlin insists that these values and moral ends are not infinitely many; they are within the human horizon. Despite the fact that the values are many, you and I can understand each of them (we can understand

conflict. The parties in a conflict need something common in order to meet in a clash; Williams offers a similar piece of reasoning for explaining why standard cultural relativism does not offer a reasonable account of conflict, it is either too early (there is yet no contact needed for conflict) or too late (there is a new "we" that must be negotiated), "Human Rights and Relativism" in Williams (2005): 65.

i Berlin (1990): 11; pages 10 and 11 in this volume offer Berlin's strongest rejection of relativism.

ii Berlin never clearly develops his metaethical views on the nature of value. I understand his characterization of values as objective in a way that they are simply values regardless one's particular standpoint. One does not have to endorse them or act upon them but (a) they are still values and (b) whoever can acknowledge them as values. For a theory of human motivation based on this understanding of values cf. Williams, B. (1981): "Internal and External Reasons", in Moral Luck, Cambridge: Cambridge University Press, pp. 101-113.

iii $\quad$ Lilla, Dworkin, Silvers (eds.) (2001): 105. 
why they are values) when properly explained. However, this does not mean that we have to endorse all of them. According to Berlin this is not only absurd but basically impossible.

These collisions and conflicts are not only contingent; they are not given by the imperfect particularities or epistemic failures of human kind. The conflict of values, Berlin insists, is "of the essence of what they are and what we are. [...] Some among great goods cannot live together. That is a conceptual truth." ${ }^{\text {, It }}$ is clear that Berlin does not reject the above mentioned point (i) concerning "natures": values and we, human beings, have natures. However, it is essential that they allow for a pluralistic view of values and conflicts between them.

\section{Pluralism and Liberalism}

I said above that value pluralism constitutes one part of foundations on which liberalism rests. ${ }^{\text {ii }}$ Liberalism as understood, for example, by Joseph Raz or John Gray embodies not only the ideal of toleration but pluralism of

i $\quad$ Berlin (1990): 13.

ii On this topic cf. Crowder, G. (1994) and reply by Berlin, I. and Williams, B. (1994). 
values. ${ }^{i}$ We tolerate other opinions, habits or behaviours even though we consider them mistaken or even wrong; however we tolerate them because we either understand toleration to be good in itself or because it brings overall better results than any other option. On the other hand, pluralism of values understands other ways of life and opinions as genuinely valuable but incompatible within a single life of an individual or community. The political dialogue within liberal society can be a dialogue of two positions which understand each other's respective value but nevertheless stand in opposition.

Society respecting the plurality of values tends less to compel its citizens to share only one ideology or way of life. ${ }^{\text {ii }}$ This is one sense in which we call society "liberal" and we see how pluralism could be used (in certain cases) as an argument against state paternalism. In this respect value pluralism respects the autonomy of human beings as opposed to the "life of coerced choices". iii A liberal environment respects one's autonomy and choice.

i Cf. Gray (2000) ch. 2 and "What is dead and what is living in liberalism" in Gray (1993): 283-328; Raz (1986) ch. 14 "Autonomy and Pluralism".

ii Cf. Williams (1999): xix.

iii $\quad \operatorname{Raz}(1986)$ : 371, cf. 391ff. 
Value pluralism enables a society to take seriously the claims and complaints of its different groups and parts. ${ }^{\mathrm{i}}$ If a group or minority in society claims that certain political decision promo-ting liberty violated, for example, their claim in equality, we do not have to presuppose that there is inevitably something wrong with their notion of equality as a political value. The pluralistic conception of conflict does not have to assume that at least one side of the conflict must necessarily be wrong. On the contrary, value pluralism allows for a respectful conflict of different parties and therefore for a serious dialogue on important issues with both parties listening to the other one. ${ }^{\text {ii }}$

In his Two Faces of Liberalism John Grey presents us with a somewhat similar line of thought. ${ }^{\mathrm{iii}}$ What we need, Gray says, are not universal common values but common institutions that allow for coexistence of different ways of life and world-views. Value pluralism then justifies this institutional framework on moral grounds. He does not consider the liberal state or ideology to be the only

i Lilla, Dworkin, Silvers (eds.) (2001): 99ff.

ii Raz (1986): 249 talks about sensitivity of people to "the motives behind various offers and to their symbolic significance", my claim is that the value pluralism allows for acknowledgement of relevance and significance even of two opposed options or opinions.

iii $\quad$ Gray (2000) in passim. 
AlӨHP II. 4 International Issue

necessary one fitting for this task of establishing a modus vivendi for our life in peace, but nevertheless he agrees that it is the most appropriate one.

I do not claim in the following section that Sophocles' Antigone or any of the characters presents any kind of a worked-out liberal doctrine. The only point I want to make is that two minor characters, Haimon and Ismene, try to think about a modus vivendi for Thebes which includes both parties of conflict, Creon and Antigone, under one roof without demanding an unconditional surrender of either of them. In this respect I will try to trace some aspects of their understanding of value pluralism (without assuming that Sophocles had any theory like that on his mind).

Sophocles' Antigone: where is the tragedy, where is the conflict, where is the pluralism?

I will show in what sense Sophocles' Antigone is an example of a value conflict. And I mean what I say: the play itself presents a value conflict to the spectator (or reader). In my understanding of the play, the Antigone presents the viewers with - at least - two incompatible views on the value structure in a society. I will argue that both main characters themselves, Kreon and Antigone, are 
far from exhibiting anything like value conflict; and that only Haimon and Ismene do reflect the situation in the terms of a conflict. ${ }^{i}$ The chorus of Thebian elders in their stasima provide the spectator with some remarks on human nature that allow for a value conflict, however they do not act nor do they decide upon anything.

Hegel, perhaps the most prominent and influential interpreter of the Antigone writes that the heroes are both guilty and innocent. ${ }^{\mathrm{ii}} \mathrm{He}$, of course, prefers the interpretation in which the conflict results into a synthesis on the higher level of the development of the spirit and Sophocles' play presents for him the prime example of the conflict of obligations between family and state. ${ }^{\text {iii }}$ Goethe had already pointed out that this inter-pretation is untenable because of

i For the role of Ismene and Haimon as advisers to other characters cf. Carter (2005) who tries to rehabilitate the "minor" characters in the play. Barker (2009) in chapter 1 offers a detailed study of Haimon in relation to political philosophy.

ii $\quad$ Hegel (1975): 1214.

iii Hegel (1975): 1215: "The true development of the action consists solely in the cancellation of conflicts as conflicts, in the reconciliation of the powers animating action which struggled to destroy one another in their mutual conflict. Only in that case does finality lie not in misfortune and suffering but in the satisfaction of the spirit, because only with such a conclusion can the necessity of what happens to the individuals appear as absolute rationality, and only then can our hearts be morally at peace: shattered by the fate of the heroes but reconciled fundamentally.“ 
AlOHP II. 4 International Issue

its oversimplification. ${ }^{\mathrm{i}}$ However, I will support Hegel in his understanding of the text as a conflict between two moral obligations, i.e. two different goods which exclude each other, and not a conflict between two evils or an evil and a good.

\section{Lonely titans - Kreon and Antigone}

There is Kreon on one side of the conflict and, of course, Antigone on the other. Let me first briefly sketch how I understand each of these two characters, and then I will get to Haimon and Ismene. The final paragraphs of this section will deal with the discussion of human nature and value conflict in the Antigone.

Kreon is depicted as a typical technocrat of power; he perceives himself as a saviour of the city whose only task is to lead it straight after the times of turmoil and unrest. His very first appearance ought to make two things clear: Kreon is the ruler and he will rule for the sake of the polis, regardless of what ends. ${ }^{\mathrm{ii}} \mathrm{He}$ emphasizes that he rules

i J. W. Goethe in conversation with J. P. Eckermann, 27.3.1827; in Franz Deibel (hrsgb.) (1908): Goethes Geßpräche mit J. P. Eckermann, Leipzig, 347-353.

ii Kreon's first son was sacrificed in order to save Thebes from being conquered, cf. Griffith (1999): 5, ftn. 20. For priority of polis 
because of the kinship with the dead ones. ${ }^{i}$ However, his own principles of rule have nothing to do either with gods he invokes at the beginning of his speech or with the duties to the deceased ones.

After announcing that he is the ruler, he explains that: "It is impossible ( $\dot{\alpha} \mu \eta \dot{\chi} \chi \alpha v o v)$ to know completely the

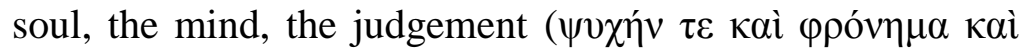
$\gamma v \omega ́ \mu \eta v)$ of a man until we see his mettle tested against his

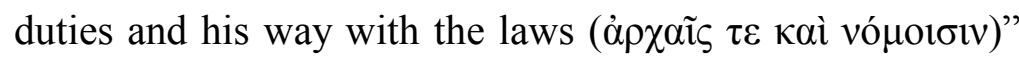
(1. 175-177). This, I believe, is Kreon's statement that is primarily not about Polyneikes but relates to Kreon himself. He is about to introduce the principles of his rule and he wants to be judged according to the way he himself keeps to them. ${ }^{\text {ii }}$ First, he sets out two examples of a bad rule (1. 178-183): someone who does not pay attention to the best advice and does not participate in public debate belongs to the worst rules; however, anyone "who feels that someone close to him is more important than his own

against the individual cf. Aristotle, Pol. I.2 1253a18; however Aristotle is moderate in keeping the private life of a citizen intact.

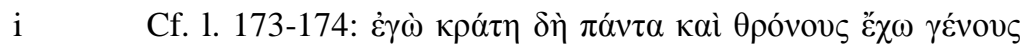
$\kappa \alpha \tau^{\prime} \dot{\alpha} \gamma \chi 1 \sigma \tau \varepsilon \tilde{\alpha} \alpha \tau \tilde{\omega} \nu$ ó $\lambda \omega \lambda$ ó $\tau \omega v$. Unless said otherwise, I use the text from Griffith (1999) and the translation by Reginald Gibbons and Charles Segal published in 2003 by Oxford University Press.

ii This passage is moreover framed by two uses of first person singular pronoun: $\dot{\varepsilon} \gamma \dot{\omega}$ at 173 and $\dot{\varepsilon} \mu o \grave{~ a t ~} 178$. 
fatherland" does not even exist for him. ${ }^{\mathrm{i}}$ On the other hand, Kreon himself ( $\dot{\gamma} \gamma \omega \grave{\gamma} \gamma \alpha \dot{\rho} \rho$ at 1. 184) would never be silent if any danger approached the city nor would he love an enemy of the city as a friend (1. 184-188). These are the principles of his rule to which he will absolutely adhere. ${ }^{\text {ii }}$

He considers the polis as a ship which has to have a strong captain; this image is used twice during his speech (1. 162-3 and 189-190). ${ }^{\mathrm{iii}}$ This picture always relates to the polis in danger and compares it to a ship in some difficulty at sea. Sea voyages were extremely dangerous and risky therefore I take it that in using this image Kreon wants to suggest the supremacy of the interest of the state over those of individual citizens. ${ }^{\text {iv }}$ As a captain is the only master on

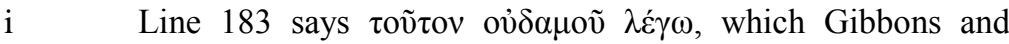
Segal translates as "him I count as belonging nowhere", makes a nice reference to the hopeless and desperate situation of anyone who in ancient Greece does not belong to a city or family. I take it that the expression might be even stronger, cf. LSJ page 1268 ad ov̉ $\alpha \mu \mu$ I.2.

ii Therefore he later emphasizes (1. 657) that he will not lie to

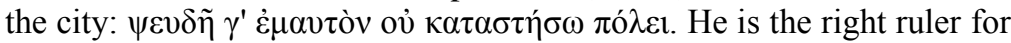
he is devoted to the polis and never distances himself from its rules, cf. 1. 1113-1114 as well. It is, of course, in understanding these rules and their origins where a deeper problem resides.

iii The image of "the ship of state" is attested well before Sophocles (in Alcaios, Theognis or Aeschylos), cf. references in Nussbaum (1986): 438-9, ftn. 25.

iv Nussbaum (1986): 55, argues that the ship is only a means for different ends of its different sailors or passengers. First, I am not sure there are any passengers in this image (i.e. people not involved in 
the sea, Kreon understands himself to be the only master in a polis:

Whoever is put into power by

The city must be obeyed in everything -

In small things, and what's just, and the opposite.

There is no greater evil than lack of rule. (1. 666-668)

There is no bigger evil according to him than a lack of rule

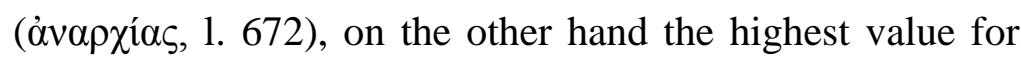
him is $\pi \varepsilon 1 \theta \alpha \rho \chi i \alpha$, obedience (1. 676). Peitharchia is actually the same characteristic which is highly praised by Eteokles in Seven Against Thebes; however, already in Aeschylus the chorus reminds Eteokles that obedience is the mother of success "but the power of God is supreme". The term suggests obedience connected with subordination and so to say unconditional surrender of one's own interests. ${ }^{\text {ii }}$

political life, I understand the image that all the citizens are sailors), second Nussbaum overlooks the realities of ancient sea voyages where the only goal of all the people (once on the sea) was to reach the destination safely and therefore they were unconditionally subordinate to the captain of the ship for the length of their journey.

i Aes. Th. 224-229.

ii Cf. Aristotle, Pol. 1262b3; cf. Isocrates, Panath. 111.6, he names $\pi \varepsilon \imath \theta \alpha \rho \chi i \alpha$ as a feature that is characteristic for Spartans as opposed to Athenians. 
AlӨHP II. 4 International Issue

Moreover, directing a ship is a kind of techne, craft of sailing; Kreon wants to suggest that steering or managing a polis is a question of proper technical knowledge similarly as steering a ship. When confronted with Antigone he replies to her:

Understand that rigid wills are those

Most apt to fall, and that the hardest iron,

Forged in fire for greatest strength, you'll see

Is often broken, shattered. And with only

A small sharp bit, I've noticed, spirited

Horses are disciplined. For grand ideas

Are not allowed in someone who's the slave

Of others ... (1. 472-478)

All these technical analogies are used here in order to describe Kreon's attitude to men and his political subjects. Kreon sees the political work simply as a kind of technical behaviour that demands obedience and uniformity from its subjects. When Antigone calls him a tyrant (1. 506) - this term does not have all its negative connotations yet $^{\mathrm{i}}-$ he

i Sophocles writes the Antigone in 442 or 441 during democracy, well before tyrannical rule in Athens. Cf. Benardete (1975b): 16-17. 
replies that she is the only one to think so; Antigone replies that the others are merely silenced and perhaps afraid to talk. Kreon surprisingly does not dispute this but he asks whether she is not ashamed for not thinking as they do (1. 510 ), i.e. he considers diversity and independence of views to be something shameful. ${ }^{\mathrm{i}}$

Thus Kreon has sunk into the identification of his own person with his polis so that any opposition or dissent from his views and wants is conceived in the terms of treason for a despicable profit. ${ }^{\mathrm{ii}}$ When he introduces his decree concerning Polyneikes he can imagine only one reason for which someone could attempt to break it and that reason is profit ( $\kappa \dot{\varepsilon} \rho \delta o \varsigma, 1.222$ ). He reconfirms his view right after finding out that someone attempted to do the funereal rituals. After harshly rejecting the idea of chorus

i In this respect his rule resembles communist regimes in Central and Eastern Europe in the seventies and eighties: the difference from mainstream or from an official point of view is viewed as something faulty, unwanted, shameful and in the end criminal.

ii Barker (2009): 25 claims that this identification with polis is far from identification of one's rule with the rule of law, Kreon falsely accuses Teiresias and is ready to punish him without any support in the law. Similarly Benardete (1975a): 156 and 173 claims that Kreon identifies a decree and law on a completely nondemocratic basis, cf. Benardete's comment on ö $\sigma \tau \iota \varsigma$ at 1. 661 and 663; Benardete rightly observes that Kreon considers his interest qua ruler to be identical with his interest qua person, Benardete (1975b): 33-34. Kreon's identifies himself with polis and therefore loses himself as a person. 
that the gods might be responsible for it (1. 280ff.), he quickly moves to the idea of some civic complot or conspiracy (1. 289-292). The unsatisfied citizens are "the ones who bribed the guards to do this" (1. 293-4). Kreon cannot conceive of an opposition except for a conspiracy aiming at some gain which uses bribes to subvert his rule. Until the very end of the play he considers Antigone and Ismene as part of a political conspiracy against his political rule (cf. 525).

Antigone actually acknowledges that some gain or

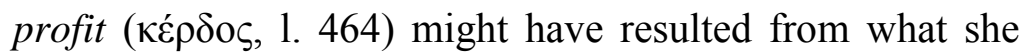
did. However, it is an absolutely different profit than Kreon had in mind. It is a gain of being dead, being in the company of the deceased from one's own kin (1. 465ff). Antigone's fascination with death (thanatos), which she prefers to loving life with Haimon (eros), is a well described topic. ${ }^{\mathrm{i}}$ Her decision to bury Polyneikes is supported with the claim that her act makes her death a beautiful one

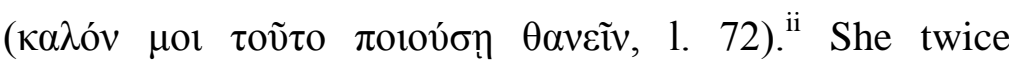
mentions that her deeds must be attractive for the dead ones below the earth $(1.75,89)$.

i Benardete (1975a): 194 aptly remarks that for Antigone "death is not the limit but the goal".

ii $\quad$ Cf. $\kappa \alpha \lambda \tilde{\omega} \varsigma \theta \alpha v \varepsilon \tilde{v}$ at 1. 97. 
Antigone is devoted to the dead of her family, to chthonic deities and to their laws or decrees; when confronted with Kreon she claims that his decree is less valid than those given by the gods:

Nor did I think your proclamation so strong

That you, a mortal, could overrule the laws

Of the gods, that are unwritten and unfailing. (1. 453-455) ${ }^{i}$

At one moment Antigone compares herself to a daughter of Tantalus, Niobe (1. 823 ff); chorus immediately warns her not to mix categories, since Niobe was from the race of the gods whereas they are just mortal human beings (1. 834839). It seems that Antigone is too quick in transgressing boundaries between human beings and gods, between mortals and the dead (treated as immortals).

Kreon after the confrontation with Teiresias

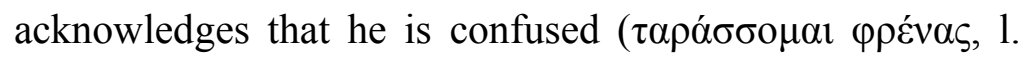
1095), asks for advice (1. 1099) and even changes his mind (1. 1105-1106), Antigone remains confident (and therefore

i Cf. Heraclitus' fragment B114: “Those who speak with sense must rely on what is common to all, as a city must rely on its law and with much greater reliance: for all the laws of man are nourished by one law, the divine law; for it has as much power as it wishes and is sufficient for all and is still left over." 
commits the radical act of suicide as well) until the very end. The only place where she reveals certain insecurity is on lines 923-928: "If all this does seem good to the gods, then I through suffering would know within myself that I did wrong ..." That is the only place where she seems to acknowledge - quite formally - that her point of view might not be the correct one.

Antigone makes clear in her last words that she understands her situation as a tragic one: she calls her tomb a bridal chamber (1. 891) and describes herself as the last and worst among the shadows (1. 895) and as a suffering being (1. 943). However, her confidence about the right way of action remains unshaken. Kreon, on the other hand, stays alive in order to suffer the loss and the tragedy of his situation. Moreover, as I showed above, at one moment he acknowledges his guilt and his mistakes. How could one decide which of them is more tragic? Is it the living, shattered, suffering, aging man or the demonic teenage felode-se? ${ }^{\mathrm{i}}$

Moreover, they both share one another's characteristics: loneliness. Antigone herself describes her departure from this world as a departure of someone who

i It might be quite revealing to realize that Antigone is about fifteen or even younger; fifteen was the usual marriage age in ancient Athens. In our eyes she is rather a young girl than a mature woman. Kreon therefore sends to death a fifteen year old. 
goes "without weeping, without friends, without marriage"

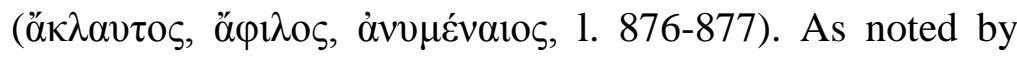
Benardete, Antigone from the very beginning distinguishes herself from all others and especially from Ismene: their evils are different; they do not share in suffering the same

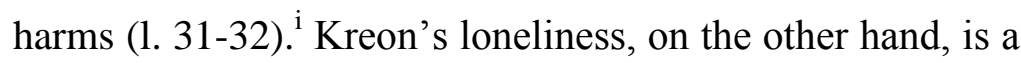
loneliness of a tyrant recognized and described by Hannah Arendt: "the delusion of extraordinary strength arises and with it the fallacy of the strong man who is powerful because he is alone." "ii Haimon touches this point when in a sharp discussion he discloses his solitude:

K: Must I rule this land for someone else, not myself?

$H$ : There is no city that belongs to one man only.

$K:$ Isn't the city held to be his who rules?

$H$ : You'd do well as the single ruler of some deserted (eremos) place. (1. 736-739)

Kreon misses all the essence of a human community and his rule could be successfully exercised in a deserted realm. Subsequently, Kreon says that Antigone will be "isolated"

Benardete (1975a): 150.

ii $\quad$ Arendt (1998): 190. 
AlӨHP II. $4 \quad$ International Issue

(eremos, 1. 887 cf. 919) and sentences her to be abandoned in a cave in a "deserted" (eremos, 1. 773) place. ${ }^{\mathrm{i}}$

\section{The weak in between - Ismene and Haimon}

What Haimon actually tries to do (and I will try to show that Ismene has a similar goal) is to keep the plurality within the polis. From his very first lines he makes clear that he wants to reconcile his father's will with Antigone's life - even at the cost of their marriage (1. 635-638). He appeals to reason ( $\varphi \rho \eta ́ v, 1.683)$ and questions Kreon's idea of his own infallibility: "someone else might also have a good thought " (1. 687). ${ }^{\mathrm{ii}}$ Similarly Ismene three times demands from her sister to stop and think or to be prudent (1. 49, 61, 68). Barker stresses that Haimon's conception of reason includes dialogue - talking and listening to others. ${ }^{\text {ii }}$ Acouple of lines later he again invites Kreon to leave the thought that only what he says himself is correct:

i This point is developed in Segal (1966): 80-81.

ii On the one-sidedness of Kreon's concept of "reason" and other values, cf. Nussbaum (1986): III.2. Nussbaum acknowledges that the tragedy makes us more receptive to plurality of values, p. 78.

iii Barker (2009): 19. 
So don't invest

Your being in one single way to feel -

That what you say, but nothing else, is right. (1. 705-706)

$\mathrm{He}$ seems to argue for a plurality of opinions; he acknowledges how complicated the situation is. For Haimon "there is no shame in learning many things" (1. 710-1). ${ }^{\mathrm{i}} \mathrm{He}$ stresses that one should yield to a better argument, better reasoning, regardless of who is author (1. 718-723). ${ }^{\text {ii }}$ When confronted with Kreon Haimon makes clear that despite what his father does, he still acknowledges him as his father. This attitude changes during their discussion, but the opening is clear enough. This is very similar to the position of Ismene to her sisters. Despite the fact that she considers Antigone's action mad and perhaps wrong, she still cares about her:

If you think so, then go. But know you're foolish

i Haimon represents here the fox of Berlin's typology based on Archilochus' poem (fox stands for those who know many small things, whereas hedgehog knows one big thing), cf. Lukes in Lilla, Dworkin, Silvers (eds.) (2001): 43ff.

ii His line of reasoning parallels Hesiod's praise of an excellent man (panaristos) at Works and Days 295-297. 
AlӨHP II. 4 International Issue

To go, yet rightly dear to your dear ones. (1. 98-99) ${ }^{i}$

The structure of the last line entails the simple syntactic device $\mu \dot{\varepsilon} v \ldots \delta \dot{\varepsilon} \ldots$ that usually serves to mark stronger or weaker contrast of various kinds. ${ }^{\text {ii }}$ Perhaps the most telling rendering is on the one hand ... on the other hand .... Ismene actually uses this conjunction twice to describe her opinion: on the one hand she understands her sister, on the other she is aware of other obligations as well (above quoted line 99 and 78-79). Antigone and Kreon use it almost entirely to stress the difference between them, following the right course of action, and the good-fornothing others (1. 80-81, 162-4, 555-9, 669). Unsurprisingly this syntactic conjunction is used in Antigone's as well as in Kreon's first expressions of doubt and uncertainty (1. 925-8 for Antigone and 1105 for Kreon).

Ismene's and Haimon's ability is to seriously consider several options and to be aware of more possible and correct ways of acting together. ${ }^{\text {iii }}$ They both seem to understand both sides of the conflict - and that is why they

i Although Antigone considers "the dear ones" to be the dead ones of her kin, Ismene thinks of herself, Haimon and other living relatives and friends.

ii $\quad$ Smyth (1920): p. $656 \S 2904$.

iii Cf. similar opinion in Saxonhouse (1992): 70-1. 
become aware of the tragedy involved in the situation exactly in the way Berlin talks about the tragedy of a value conflict. They see that Kreon and Antigone endorse different values - nevertheless they acknowledge the attitudes of both of their relatives as (at least partially) correct. They do not push for a simple solution rather they ask the rivals to reconsider their limited point of view. Moreover, it is important to remember that Ismene and Haimon do not try to harmonize a good option with an evil one. It would not be right to try to reconcile a good with an evil. Rather, their aim is to reconcile two different and incompatible goods.

The life in the polis has an essential value to all ancient Greeks (cf. Plato, Protagoras 322b ff. or Aristotle, Politics 1253a3 ff.). Ismene and Haimon acknowledge the role of the personal but at the same time claiming that the personal is not the political. They respect a certain plurality in their lives and make it clear that they can live in the world that is not entirely according to their own views. Ismene and Haimon seem to be aware of what Arendt calls "boundlessness of action" and therefore of a risk which someone runs when one takes an absolute standpoint (or course of action) without any moderation. ${ }^{\text {i }}$

i $\quad$ Arendt (1998): 190-191. 
In order to avoid these risks, they accept some elementary value pluralism and try to view more options as being possibly the correct and valuable ones. Ismene tries to convince Antigone and Haimon attempts the same with Kreon that other ways of life and other opinions might have some truth. However, Antigone is fully devoted to "the justice that dwells with the gods below" (1.451) and does not recognize any other values; in this respect she is fully "a law to herself" (autonomos, 1. 821). Kreon, on the other hand, levels out any differences between private and public. He claims that "he who is a good man in his domestic affairs will be shown just in the city too" (1. 662-663). Charles Segal notes that "Kreon ... lacks a deep awareness of the complexities within the human realm,"i and the same must also be said of Antigone .

Neither Kreon or Antigone recognize the necessary plurality within the polis as stressed by Aristotle (Polt. 1261a18). This plurality, Berlin's claim goes, cannot be politically and socially managed without necessary losses. The democratic society of ancient Athens was far from what we call democracy nowadays. However, one basic claim can be made. Liberalism is ambivalent about purely procedural democracy "because of the potential of

i

Segal (1966): 69. 
tyrannical majorities to interfere with individual freedoms", The behaviour to political minorities should form an important part in our judgement concerning political ideologies and regimes. ${ }^{\mathrm{ii}}$ My claim is that since value pluralism is a moral ground for liberalism (or it forms an essential part of such a ground), liberalism has a better array of options of how to behave towards political minorities than other ideologies based on monistic ethical systems.

In this respect, as I have already mentioned above, value pluralism stands as a possibility against the idea of toleration. We tolerate something we consider wrong but for some other reasons we accept this otherwise unworthy feature next to our lives. ${ }^{\mathrm{iii}}$ On the other hand, value pluralism assigns positive value to other options, other ways of life, other customs or other decisions. If we accept value pluralism as a correct metaethical description of the reality, we can acknowledge the otherness of minorities as having some positive value rather than merely tolerating them.

i $\quad$ Barker (2009): 8 .

ii I reduce my claim to "political minorities", i.e. those parties who have their representation in a political dialogue; of course the relation to all other possible minorities is an important issue, but it is too complicated for this essay.

iii Cf. Williams (2005): 128-138 and Williams (2006): 126-134. 


\section{AlӨHP II. 4 International Issue}

I tried to make clear that in the lines which Sophocles puts into mouth of Ismene and Haimon we can find some elementary traces of this view. According to my interpretation Ismene and Haimon offer a plural view on the social reality of ancient polis that can serve to highlight the importance of an analogous standpoint in our contemporary society. As I said at the beginning of this essay, one cannot reasonably claim that Sophocles or any of its characters are anything like liberals. However, I attempted to show that recognizing the pluralism of values and its possible tragic outcomes might indeed prevent much worse tragedies. 
AlOHP II. $4 \quad$ International Issue

\section{Bibliography:}

Arendt, H. (1998): The Human Condition, The University of Chicago Press.

Barker, D.W.M. (2009): Tragedy and Citizenship, State University of New York Press.

Benardete, S. (1975a): "A reading of Sophocles' Antigone I" in Interpretation 4/3, 148-196.

Benardete, S. (1975b): “A reading of Sophocles' Antigone II" in Interpretation 5/1, 1-55.

Benardete, S. (1975c): “A reading of Sophocles' Antigone III" in Interpretation 5/2, 148-184.

Berlin, I. (1990): The Crooked Timber of Humanity, Princeton University Press.

Berlin, I. (2004): Liberty, Oxford University Press.

Berlin, I. and Williams, B. (1994): "Pluralism and Liberalism: a Reply" in Political Studies XLI, 306-309.

Carter, D.M. (2005): "The co-operative temper: A third dramatic role in Sophoclean tragedy" in Mnemosyne LVIII/3, 161-162. 
AlӨHP II. 4 International Issue

Crowder, G. (1994): "Pluralism and Liberalism" in Political Studies XLII, 293-305.

Gibbons, R. and Segal, Ch. (2003): Sophocles - Antigone, Oxford University Press.

Gray, J. (1993): Post-Liberalism, Routledge.

Gray, J. (2000): Two Faces of Liberalism, Polity Press and Blackwel Publishers Ltd.

Griffin, J. (1998): "The social function of attic tragedy" in Classical Quarterly 48/1, 39-61.

Griffith, M. (1999): Sophocles - Antigone, Cambridge University Press.

Hegel, G. W. F. (1975): Aesthetics II, Claredon Press.

Holmes, S.T. (1979a): "Aristippus in and out of Athens" in The American Political Science Review 73/1, 113-128.

Holmes, S.T. (1979b): "Aristippus in and out of Athens: A Reply to Nichols" in The American Political Science Review 73/1, 134-138.

Lilla, M., Dworkin, R., Silvers, R. B. (eds.) (2001): The Legacy of Isaiah Berlin, New York Review Books. 
AlӨHP II. 4 International Issue

Melegari, D. (ed.) (1895): Journal intime de Benjamin Constant et lettres à sa famille et à ses amis, Paul Ollendorf.

Nichols Jr., J.H. (1979): "On the Proper Use of Ancient Political Philosophy" in The American Political Science Review 73/1, 129-133.

Nussbaum, M. C. (1986): The Fragility of Goodness, Cambridge University Press.

Raz, J. (1986): The Morality of Freedom, Claredon Press.

Rhodes, J. P. (2003): "Nothing to do with democracy: Athenian drama and the polis" in Journal of Hellenic Studies 123, 104-119.

Saxonhouse, A. W. (1992): Fear of Diversity: The Birth of Political Science in Ancient Greece, Chicago University Press.

Seaford, R. (2000): "The social function of attic tragedy: A Response to Jasper Griffin" in Classical Quarterly 50/1, 30-44.

Segal, Ch. P. (1966): "Sophocles' Praise of Man and the Conflicts of the Antigone" in: Woodard, Th. (ed.): Sophocles - A Collection of Critical Essays, Prentice-Hall, 62-85. 
AlӨHP II. 4 International Issue

Skorupski, J. (1996): "Value-Pluralism" in Archard, D. (ed.) Philosophy and Pluralism, Cambridge University Press, 101-115.

Smyth, H. W. (1920): Greek Grammar for Colleges, American Book Company.

Vincent, K. S. (2000): "Benjamin Constant, the French Revolution, and the Origins of French Romantic Liberalism" in French Historical Studies 23/4, 607-637.

Williams, B. (1981): Moral Luck, Cambridge University Press.

Williams, B. (1999): "Introduction" in Berlin, I. Concept and Categories, Pimlico, xiii-xx.

Williams, B. (2005): In the Beginning There Was a Deed, Princeton University Press.

Williams, B. (2006): Philosophy as a Humanistic Discipline, Princeton University Press. 